\title{
Structural analysis of fertilization in the fish Brycon orbignyanus
}

\author{
Luciana Nakaghi Ganeco, ${ }^{1,2}$, Irene Bastos Franceschini-Vicentini, and Laura Satiko Okada Nakaghi, ${ }^{2,4}$ \\ Depto. Morfologia e Fisiologia Animal, Faculdade de Ciências Agrárias e Veterinárias and Depto. Ciências Biológicas, \\ Faculdade de Ciências, Universidade Estadual Paulista (UNESP); and Aquaculture Center (CAUNESP), São Paulo, Brazil
}

Date submitted: 30.05 .2008 . Date accepted: 22.09.2008

\section{Summary}

In the present work, we analyzed the structure of oocytes and fertilized eggs of the piracanjuba fish (Brycon orbignyanus) under light and scanning electron microscopy. After inducing spawning, samples were collected at the moment of oocyte extrusion, when oocytes and semen were mixed (time 0 ), as well as at 10, 20 and $30 \mathrm{~s}$ after mixing, every minute up to $10 \mathrm{~min}$, and then at 15 and $20 \mathrm{~min}$. The oocytes are spherical, translucent and greenish with a mean diameter of $1.3 \pm 0.11 \mathrm{~mm}$. During the extrusion, cytoplasmic movement was observed in eggs towards the micropyle, characterizing the animal pole. At the moment of fertilization, the cortical cytoplasm showed a higher concentration of cortical alveoli at the animal pole than at the vegetal pole. The cortical alveoli breakdown promoted the elevation of the chorion with a consequent increase in egg diameter $(1.95 \pm 0.08 \mathrm{~mm})$. The penetration of the spermatozoon promotes the formation of a fertilization cone of spherical external structure, which obstructs the opening of the micropyle. This structure acts as a main mechanism to avoid polyspermy, intercepting the access of supernumerary spermatozoa. Such studies about the reproductive biology of fish are important to species survival and conservation programmes.

Keywords: Egg, Fertilization, Fish, Micropyle, Microscopy

\section{Introduction}

Fertilization is a process of cellular fusion (Ohta, 1991), encompassing the contact between the spermatozoon and the oocyte up to the union of the nuclei of both cells (Schatten, 1999; Moore, 2001). This phenomenon promotes the activation of the female gamete, which triggers the end of meiosis, previously stuck at metaphase II (Moore, 2001). Therefore, a series of events is initiated that include: depolarization of the plasma membrane of eggs, spermatozoon penetration, cortical alveoli breakdown, formation of the perivitelline space and completion of meiosis (Iwamatsu, 1992; Ohta \& Nashirozawa, 1996).

\footnotetext{
${ }^{1}$ All correspondence to: L. Nakaghi Ganeco. Departamento de Morfologia e Fisiologia Animal, UNESP-São Paulo State University, Via de Acesso Prof. Paulo Donato Castellane, s/n, CEP 14884-900, Jaboticabal, SP, Brazil. Tel:/Fax: +55 163209 2654. e-mail: Inganeco@yahoo.com.br

${ }^{2}$ Aquaculture Center (CAUNESP)-Jaboticabal-SP, Brazil.

${ }^{3}$ Depto. Ciências Biológicas, Faculdade de Ciências-UNESP, Bauru-SP, Brazil.

${ }^{4}$ Depto. Morfologia e Fisiologia Animal, Faculdade de Ciências Agrárias e Veterinárias-UNESP, Jaboticabal-SP, Brazil.
}

The spermatozoon penetrates through an opening, the micropyle, located on the egg's animal pole in teleosteans (Kudo, 1980; Kobayashi \& Yamamoto, 1981; Hart, 1990; Iwamatsu, 2000). The first spermatozoon that reaches the micropyle and penetrates it will interact with the microvilli found on the oocyte plasmatic membrane (Hart \& Donovan, 1983; Iwamatsu, 2000).

As fertilization in fish is generally monospermatic (Kobayashi \& Yamamoto, 1981), after the first spermatozoon penetration, mechanisms that prevent polyspermy should take place. These include mechanical barriers, such as the closure of the internal opening of the micropyle (Brummett \& Dumont, 1979; Kobayashi \& Yamamoto, 1981; Hart \& Donovan, 1983, Kudo et al., 1994), formation of the fertilization cone (Kudo, 1980; Iwamatsu et al., 1991; Linhart \& Kudo, 1997; Freire-Brasil et al., 2002) and activation of the cortical reaction in order to eliminate any supernumerary spermatozoa (Iwamatsu \& Ohta, 1981; Iwamatsu et al., 1993).

Fertilization events have been studied in several fish species, such as Fundulus heteroclitus (Brummett \& Dumont, 1979), Cyprinus carpio (Kudo, 1980), Oryzias 
latipes (Iwamatsu \& Ohta, 1981; Iwamatsu et al., 1991), Oncorhynchus keta (Kobayashi \& Yamamoto, 1987), Oreochromis niloticus and O. aureus (Bern \& Avtalion, 1990), Rhodeus ocellatus ocellatus (Ohta, 1991; Ohta \& Nashirozawa, 1996), Silurus glanis (Kudo et al., 1994), and Polyodon sphatula (Linhart \& Kudo, 1997). However, fertilization studies in Brazilian fish species have received little attention so far. Reports on fertilization events are available for Prochilodus lineatus, used as an experimental model (Freire-Brasil et al., 2002) and, subsequently, other studies have been carried out in some native species at the Aquaculture Center UNESP, as follows: Salminus brasiliensis (Nakaghi et al., 2006), Pseudoplatystoma coruscans $\times$ P. fasciatum hybrids (Faustino et al., 2007), P. coruscans (Marques et al., 2008), Paulicea luetkeni and Brycon amazonicus (Nakaghi, unpublished data). Studies that involve native fish species are essential to provide both a better knowledge about their biology and reproductive features and a proper management in fish culture systems.

Brycon orbignyanus (piracanjuba) is a tropical fish from South America found in Paraná, Uruguay and Paraguay basins, as well as in Bolivia and the Amazon basin (Nakatani et al., 1999). This species is of great economic interest as it has high quality meat, fast growth, easy farming, besides being very popular as a sport fishing species because of its aggressive behaviour (Vaz et al., 2000). Nevertheless, this species has become endangered as a consequence of constraints in the reproductive migration caused by the large number of dams along river channels and environmental degradation (Paiva, 1982; Vaz et al., 2000). In addition, the spawning of B. orbignyanus in captivity has been hindered by the interruption of the gonadal cycle and successful reproduction can only be achieved artificially by hormonal induction. Therefore, studies on the reproductive biology of this species are important to assure its survival. Based on the scarcity of data about the fertilization events in South American fish and the necessity of conservation of $B$. orbignyanus in order to avoid its extinction, the goal of the present work was to characterize the first fertilization stages of this species under light and scanning electron microscopy.

\section{Materials and methods}

\section{Sampling}

Samples were collected at Estação de Pesquisa e Desenvolvimento Ambiental de Volta Grande, Conceição das Alagoas, Minas Gerais (CEMIG Companhia Energética de Minas Gerais) and at the Aquaculture Center of UNESP (CAUNESP). Spawning was induced in adult piracanjuba (Brycon orbignyanus) specimens between November and January - the reproductive season of this species. The females received three inoculations of Cyprinus carpio, common carp pituitary extract. Two doses $(0.25 \mathrm{mg} / \mathrm{kg}$ and $0.5 \mathrm{mg} / \mathrm{kg}$, respectively) were applied in a $4 \mathrm{~h}$ interval, and the third dose $(5 \mathrm{mg} / \mathrm{kg})$ was applied after $12 \mathrm{~h}$. Ovulation occurred $4 \mathrm{~h}$ after the third application. The males received a dose of $5 \mathrm{mg} / \mathrm{kg}$ at the time of the third dose in females.

After extrusion, the oocytes were carefully mixed with sperm. Hydration occurred 1 minute later, when the oocytes were transferred into a 16001 aquarium equipped with water exchange, temperature at $27^{\circ} \mathrm{C}$, and aeration system.

The samples were collected at the moment of oocyte extrusion, when oocytes and sperm were mixed (time 0 ), at 10, 20 and $30 \mathrm{~s}$ after mixing, every minute up to $10 \mathrm{~min}$ and then, at 15 and $20 \mathrm{~min}$.

\section{Light microscopy}

The samples were fixed in Karnovsky's solution or 10\% buffered formol for $24 \mathrm{~h}$ and washed in 70\% alcohol. After washing, the samples were dehydrated for $5 \mathrm{~min}$ in a series of 80,90 and $95 \%$ alcohol (absolute alcohol I, II and III), cleared in xylol I, II and III and then, embedded in paraplast for $20 \mathrm{~min}$. Given the biological nature of the material, the microtomy technique was adapted to obtain cuts with a good quality for further observation. Therefore, the blocks used for microtomy had the cut sides immerse in a solution of glycerin and distilled water (1:1) for 18-24 h. Histological sections were $4 \mu \mathrm{m}$ in thickness and stained with haematoxylineosin and Masson's Trichrome (Bancroft \& Gamble, 2006). Analyses were performed using an Olympus BX 50 photomicroscope.

\section{Scanning electron microscopy (SEM)}

The samples were fixed in Karnovsky's solution for $24 \mathrm{~h}$ and washed up in $0.1 \mathrm{M}$ cacodylate buffer, $\mathrm{pH}$ 7.2; post-fixed in 1\% osmium tetroxide solution for $2 \mathrm{~h}$ and washed in the same buffer solution. After, they were dehydrated in a graded series of ethanol, at 30,50,70, 80, 90 and 95\% concentrations and two baths at $100 \%$ ( $5 \mathrm{~min}$ each). The samples were then dried to the critical point in a Drier EMS 850 using liquid $\mathrm{CO}_{2}$ and metallized with gold-palladium ions in a Desk II Denton Vacuum. The material was electronmicrophotographed under SEM (JEOL-JSM 5410).

\section{Morphological analysis}

Oocyte diameter was determined using a stereomicroscope equipped with a micrometer ocular lens. Twenty oocytes were measured three times for each sampling 
period. The values were statistically analyzed using Tukey's test at $5 \%$ confidence level $(p<0.05)$.

\section{Results}

As most of teleosteans, Brycon orbignyanus presents external fertilization. The oocytes were spherical, translucent, and greenish. The average diameter after extrusion was $1.3 \pm 0.11 \mathrm{~mm}$.

Within samples collected at extrusion, the oocytes presented a cytoplasmic movement towards the micropyle, which characterizes the animal pole (Fig. 1a). Under SEM, the oocyte surface, which corresponds to the chorion or radiate zone, had pores and a single micropyle (Fig. $1 g, h$ ).

The moment the oocytes and the sperm were mixed was referred to as time 0 . At this stage, the animal and vegetative poles were formed. The vegetative pole was formed by the yolk whereas the animal pole was formed by the fused female and male pronuclei plus the displaced cytoplasm. The animal pole was basophilic and homogenous in appearance under light microscopy (Fig. 1a). The vegetative pole was acidophilic and had yolk globules (Fig. 1a), which were smaller when located closer to the animal pole (Fig. 1b). The larger globules, located in the cytoplasm and opposite to the animal pole, resulted from yolk globule coalescence (Fig. 1c).

In the cortical cytoplasm, several cortical alveoli were found aligned around the oocyte perimeter at the moment of fertilization, forming a thin basophilic layer (Fig. 1b, c). It was also observed that, after fertilizing B. orbignyanus oocytes, the number of cortical alveoli layers present in the perimeter of the egg decreased (Fig. 1a,d). These cortical alveoli were larger in size and more abundant at the vegetative pole (Fig. 1c). On the other hand, they were rarer at the animal pole (Fig. 1b, d).

As for the perivitelline space, the vegetative pole region was larger when compared to the animal pole. This feature was observed in B. orbignyanus oocytes from $10 \mathrm{~s}$ up to $5 \mathrm{~min}$ after fertilization.

It was also observed that, at time 0 , the cortical cytoplasm of oocytes presented a higher concentration of cortical alveoli in the vegetative pole in relation to the animal pole (Fig. 1a, b), indicating that the cortical reaction in piracanjuba gets started in the animal pole and proceeds towards the vegetative pole. A few cortical alveoli were observed in the cytoplasm beneath the region close to the micropyle (Fig. 1e) and the cortical reaction was not promptly observed. Thus, the reaction was probably activated by spermatozoon penetration and/or by egg hydration at $1 \mathrm{~min}$ after fertilization. The cortical alveoli breakdown promoted the chorion elevation and the consequent enlargement of the perivitelline space, which increased significantly the diameter of the eggs $(1.95 \pm 0.08 \mathrm{~mm})$ from $6 \mathrm{~min}$ on, due to the hydration level of these eggs.

After $10 \mathrm{~s}$, spermatozoa were observed around the micropyle opening (Fig. 1f). After $1 \mathrm{~min}$, several spermatozoa tails were found in the micropyle vestibule (Fig. 1g).

The penetration of the spermatozoon promoted the formation of the fertilization cone. This structure had a spherical shape at the external extremity (Fig. 1h), which obstructed the opening of the micropyle.

\section{Discussion}

The eggs of B. orbignyanus were spherical, translucent and greenish, similar to other Brycon species (Eckmann, 1984; Andrade-Talmeli et al., 2001; Romagosa et al., 2001; Reynalte-Tataje et al., 2004). In the present study, the average egg diameter of $B$. orbignyanus was equal to $1.3 \pm 0.11 \mathrm{~mm}$ after the extrusion, showing a normal size for this gender, on one occasion Vazzoler (1996) reported an average diameter of $1.55 \mathrm{~mm}$ for mature oocytes of B. orbignyanus and Romagosa et al. (2001) observed that $B$. cephalus oocytes presented an average diameter of $1.01 \mathrm{~mm}$.

A cytoplasmic movement towards the micropyle region was observed in the oocyte samples collected during extrusion, which characterized the animal pole. This cytoplasmic motion is stimulated by the fertilization (Kimmel et al., 1995). Under SEM, the oocyte surface of $B$. orbignyanus, corresponding to the chorion or radiate zone, presented pores and a single micropyle, as previously described in this species by Ganeco \& Nakaghi (2003).

An accumulation of yolk granules was observed in the vegetative pole, which decreased in size close to the animal pole. The larger granules located in the cytoplasm opposite to the animal pole resulted from the coalescence of yolk granules. Kobayashi \& Yamamoto (1985) observed that yolk coalescence in Oncorhynchus keta began at the vegetative pole, while the nuclear membrane was disintegrated.

In the cortical cytoplasm of B. orbignyanus, several cortical alveoli, aligned along the oocyte periphery, were observed at the moment of fertilization. The cortical cytoplasm surrounding the micropyle is composed of fat granules and cortical alveoli (Iwamatsu \& Ohta, 1981; Iwamatsu, 2000). Bazzoli \& Godinho (1994) analyzed mature oocytes of some freshwater teleosteans and classified the cortical alveoli of $B$. orbignyanus as discontinuous, bearing multiple layers of small vesicles, always aligned close to the radiate zone. In the present study, we noticed that 

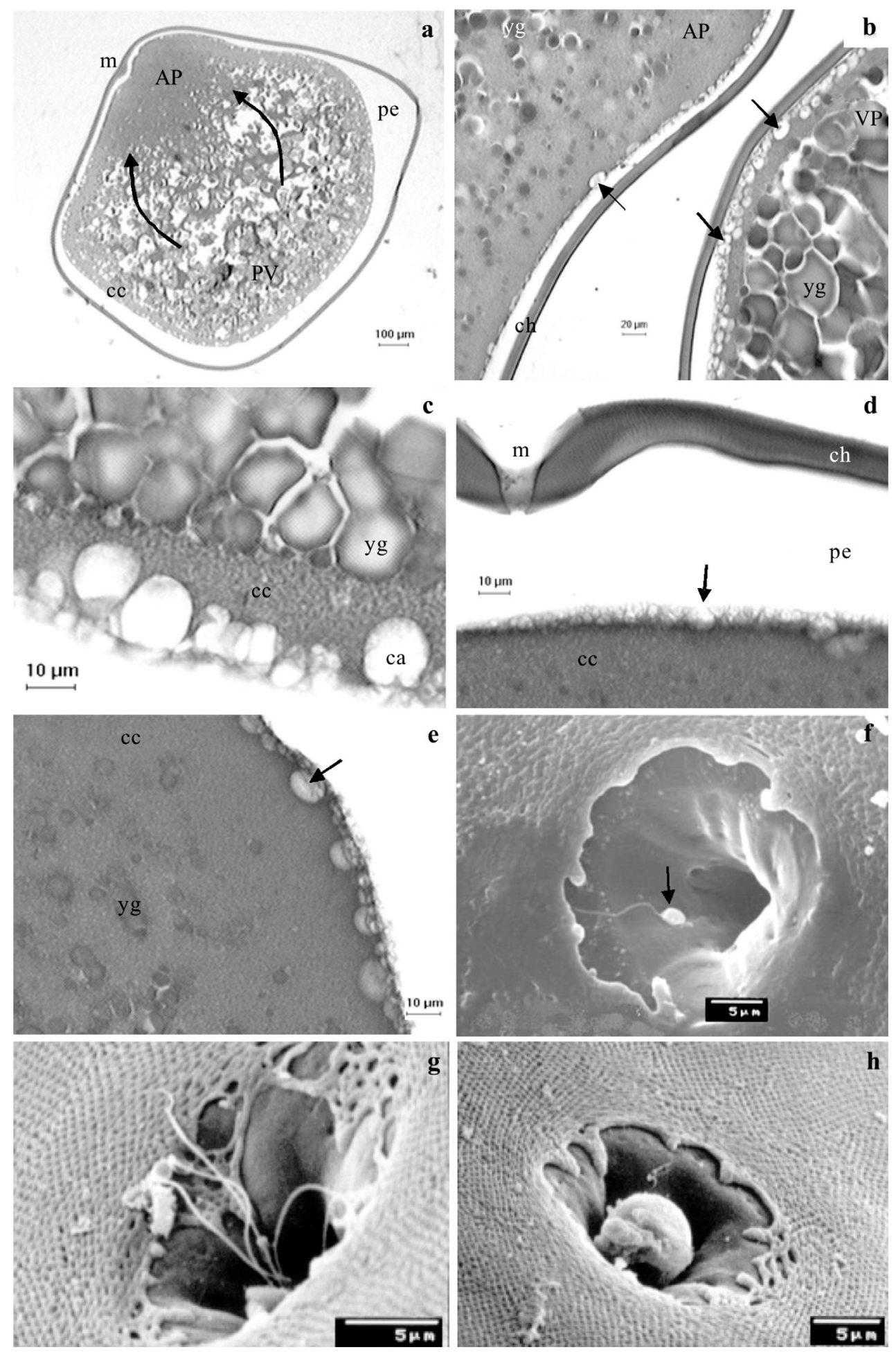

Figure 1 Oocytes and eggs of B. orbignyanus. Light photomicrography $(a-e)$; scanning electron microscopy $(f-h)$. $(a)$ Oocyte showing cytoplasmic movement (arrows) and consequent animal pole definition at time 0 (HE). (b) Egg showing cortical alveoli (arrows) in the animal and vegetative poles $10 \mathrm{~s}$ after fertilization (TM). (c) Oocyte showing the cortical alveoli (ca) in the vegetative pole at the moment of extrusion (HE). $(d, e)$ Oocyte showing cortical alveoli (arrows) in the animal pole at the moment of extrusion (HE). $(f)$ Oocyte evidencing spermatozoon (arrow) close to the micropyle opening at 1.5 min after fertilization. $(g)$ Egg evidencing the micropyle region and showing spermatozoa tails at 1 min after fertilization. The presence of pores in the chorion can also be seen. $(h)$ Egg evidencing the micropyle obstructed by the fertilization cone, resembling externally a spherical structure, at $1 \mathrm{~min}$ after fertilization. Animal pole (AP), chorion (ch), cortical alveoli (ca), cortical cytoplasm (cc), micropyle (m), perivitelline space (ps), vegetative pole (VP), yolk granule (yg). 
the number of cortical alveoli layers present in the periphery of $B$. orbignyanus oocytes have decreased after fertilization.

The perivitelline space was larger at the vegetative pole than at the animal pole. Few cortical alveoli were also observed at the animal pole, mainly within the region close to the micropyle, in other fish species as well, such as Fundulus heteroclitus (Brummett \& Dumont, 1979), Oryzias latipes (Iwamatsu \& Ohta, 1981), Oncorhynchus keta (Kobayashi \& Yamamoto, 1981), and Prochilodus lineatus (Freire-Brasil et al., 2002). According to Ohta (1985) and Hart (1990), the animal pole would present few cortical alveoli in order to delay the formation of the perivitelline space in this region thereby favouring the entrance of the spermatozoon.

The cortical alveoli breakdown and the consequent elevation of the chorion in fertilized eggs are known as the cortical reaction (Hart, 1990). This was observed in B. orbignyanus eggs $10 \mathrm{~s}$ after fertilization and lasted up to $5 \mathrm{~min}$. In this case, the reaction was probably activated by the penetration of the spermatozoon and/or by the hydration of the eggs $1 \mathrm{~min}$ after fertilization, similar to the results reported by Ohta et al. (1990) and by Kobayashi \& Yamamoto (1981) in eggs of Rhodeus ocellatus ocellatus and Oncorhynchus keta, respectively.

This cortical reaction in B. orbignyanus started at the animal pole, similar to observations in Oryzias latipes (Iwamatsu \& Ohta, 1981; Abraham et al., 1993), Polyodon sphatula (Linhart \& Kudo, 1997), Fundulus and Oncorhynchus (Hart, 1990). However, in Rhodeus ocellatus ocellatus (Ohta et al., 1990), the cortical reaction initiated at the vegetative pole towards the animal pole. It should be pointed out that the cortical reaction was not readily detected around the micropyle after fertilization, which agrees with the occurrence of few cortical alveoli in the cytoplasm immediately beneath the micropyle as a strategy to retard the formation of the perivitelline space and allow the entrance of the spermatozoon (Ohta, 1985; Hart, 1990).

The formation of the perivitelline space in the studied species and the consequent increase caused the chorion to separate from the egg membrane. This event was also observed by Laale (1980). It should be highlighted that during the cortical alveoli breakdown, ions $\mathrm{Ca}^{2+}$ are absorbed from the medium and participate in the hardening of the chorion (Iwamatsu et al., 1985; Iwamatsu, 2000), playing a key role in the mechanical protection of the developing embryo (Laale, 1980; Lönning et al., 1984).

As for the time spent by the fertilizing spermatozoon to reach the micropyle in the present study, spermatozoa were observed at the opening of the micropyle $10 \mathrm{~s}$ after sperm and oocytes were mixed up. In Fundulus heteroclitus, the presence of a fertilizing spermatozoon was observed from $3 \mathrm{~s}$ up to $3 \mathrm{~min}$ after mixing sperm and oocytes (Brummett \& Dumont, 1979). In Silurus glanis, the first spermatozoon reached the micropyle $20 \mathrm{~s}$ after fertilization (Kudo et al., 1994). In Prochilodus lineatus, the spermatozoon passed through the micropyle between 10 and $20 \mathrm{~s}$ after fertilization (Freire-Brasil et al., 2002).

In $B$. orbignyanus, the fertilization cone acted as a mechanism to suppress polyspermy, intercepting the entry of supernumerary spermatozoa. Externally, this structure was spherical. In Fundulus heteroclitus, a viscous mass released by the oocyte obstructed the micropyle after fertilization (Brummett \& Dumont, 1979). Conversely, in Oreochromis niloticus and O. aureus, the micropyle was obstructed by an amorphous mass (Bern \& Avtalion, 1990). Iwamatsu (2000) reported that this structure is similar to a bubble, composed of a perivitelline fluid released through the micropyle channel. This event is synchronized with the cortical alveoli breakdown (Iwamatsu \& Ohta, 1981). A similar mechanism was also reported in Polyodon sphatula (Linhart \& Kudo, 1997) and Oryzias latipes (Iwamatsu et al., 1991). In Prochilodus lineatus (Freire-Brasil et al., 2002), polyspermy was blocked by the presence of a spherical structure derived from inside the micropyle, but surrounded by those spermatozoa that failed in entering the micropyle channel.

According to Kudo (1980), the micropyle channel in Cyprinus carpio allows the access to several spermatozoa, suggesting that the agglomeration of supernumerary spermatozoa in the perivitelline space is required as an additional mechanism to prevent polyspermy. Ginsburg (1961) confirmed the agglutination of spermatozoa in the micropyle channel of Salmo trutta and reported that, by removing the perivitelline fluid, polyspermy was achieved in this species since it would prevent the accumulation of supernumerary spermatozoa.

The following events were described at the first moments of fertilization in B. orbignyanus: cytoplasmic movement towards micropyle in the eggs, cortical alveoli breakdown with the elevation of the chorion, the time the spermatozoon reaches the micropyle and the formation of the fertilization cone. Such knowledge is essential to a better understanding about the first stages of fish reproduction, especially of B. orbignyanus, an endangered species in Brazil.

\section{Acknowledgements}

The authors are grateful to Conselho Nacional de Desenvolvimento Científico e Tecnológico (CNPq) for the Master's scholarship to the first author; to $\mathrm{Mr}$ Orandi Mateus (FCAV/UNESP) for the histological techniques and to Estação de Pesquisa 
e Desenvolvimento Ambiental de Volta GrandeCEMIG.

\section{References}

Abraham, V.C., Gupta, S. \& Fluck, R.A. (1993). Ooplasmic segregation in the medaka (Oryzias latipes) egg. Biol. Bull. 184, 115-24.

Andrade-Talmelli, E.F., Kavamoto, E.T., Romagosa, E. \& Fenerich-Verani, N. (2001). Embryonic and larval development of the "piabanha," Brycon insignis, Steindachner, 1876 (Pisces, Characidae). Bol. Inst. Pesca. 27(1), 21-8.

Bancroft, J.D. \& Gamble, M. (2006). Theory and Practice of Histological Techniques. Churchill Livingstone (Elsevier). 5th ed. 796 pp.

Bazzoli, N. \& Godinho, H.P. (1994). Cortical alveoli in oocytes of freshwater neotropical teleost fish. Boll. Zool. 61, 301-8.

Bern, O. \& Avtalion, R.R. (1990). Some morphological aspects of fertilization in tilápias. J. Fish Biol. 36, 375-81.

Brummett, A.R. \& Dumont, J.N. (1979). Initial stages of sperm penetration into the egg of Fundulus heteroclitus. J. Exp. Zool. 210, 417-34.

Eckmann, R. (1984). Induced reproduction in Brycon cf. erythropterus. Aquaculture 38, 379-82.

Faustino, F., Nakaghi, L.S.O., Marques, C., Makino, L.C. \& Senhorini, J.A. (2007). Fertilização e desenvolvimento embrionário: morfometria e análise estereomicroscópica dos ovos dos híbridos surubins (pintado, Pseudoplatystoma coruscans $\times$ cachara, Pseudoplatystoma fasciatum). Acta Sci. Biol. Sci. 29(1), 49-55.

Freire-Brasil, D., Nakaghi, L.S.O., Santos, H.S.L., Grassiotto, I.Q. \& Foresti, F. (2002). Estudo morfológico dos primeiros momentos da fertilização em curimbatá Prochilodus lineatus (Valenciennes, 1836). CIVA 2002 (http://www.civa2002.org), pp. 733-47.

Ganeco, L.N. \& Nakaghi, L.S.O. (2003). Morfologia da superfície dos ovócitos e caracterização da micrópila de piracanjuba, Brycon orbignyanus, sob microscopia eletrônica de varredura. Acta Sci. Biol. Sci. 25, 227-31.

Ginsburg, A.S. (1961). The block to polyspermy in sturgeon and trout with special reference to the role of cortical granules (alveoli). J. Embryol. Expt. Morph. 9, 173-90.

Hart, N.H. (1990). Fertilization in teleost fishes: mechanisms of sperm-egg interactions. Int. Rev. Cytol. 121, 1-66.

Hart, N.H. \& Donovan, M. (1983). Fine structure of the chorion and site of sperm entry in the egg of Brachydanio. J. Exp. Zool. 227, 277-96.

Iwamatsu, T. (1992). Egg activation. Fish Biology. J. Medaka. 4, 1-10.

Iwamatsu, T. (2000). Fertilization in fishes. In: Fertilization in Protozoa and Metazoa Animals (Tarín, J.J. \& Cano, A. eds.) Springer-Verlag Berlin, Heidelberg. pp. 89-145.

Iwamatsu, T. \& Ohta, T. (1981). Scanning electron microscopic observation on sperm penetration in teleostean fish. J. Exp. Zool. 218, 261-77.

Iwamatsu, T., Ohta, T., Oshima, E. \& Sugiura, T. (1985). Requirement of extracellular calcium íons for the early fertilization events in the medaka egg. Dev. Growth Differ. 27, 751-62.
Iwamatsu, T., Onitake, K., Yoshimoto, Y. \& Hiramoto, Y. (1991). Time sequence of early events in fertilization in the Medaka egg. Dev. Growth Differ. 33(50), 479-90.

Iwamatsu, T., Ishijima \& S., Nakashima, S. (1993). Movement of spermatozoa and changes in micropyles during fertilization in medaka eggs. J. Exp. Zool. 266, 5764.

Kimmel, C.B., Ballard, W.W., Kimmel, S.R. \& Ullmann, B. (1995). Stages of embryonic development of the zebrafish. Dev. Dyn. 203, 253-310.

Kobayashi, W. \& Yamamoto, T. (1981). Fine structure of the micropylar apparatus of the chum salmon egg, with a discussion of the mechanism for blocking polyspermy. J. Exp. Zool. 217, 265-75.

Kobayashi, W. \& Yamamoto, T.S. (1985). Fine structure of the micropylar cell and its change during oocyte maturation in the chum salmon egg, Oncorhynchus keta. J. Morph. 184, 263-76.

Kobayashi, W. \& Yamamoto, T.S. (1987). Light and electron microscopic observations of sperm entry in the chum Salmon egg. J. Exp. Zool. 243, 311-22.

Kudo, S. (1980). Sperm penetration and the formation of a fertilization cone in the common carp egg. Dev. Growth Differ. 22(3), 403-14.

Kudo, S., Linhart, O. \& Billard, R. (1994). Ultrastructural studies of sperm penetration in the egg of the European catfish, Silurus glanis. Aquat. Living Resour. 7, 93-8.

Laale, W.H. (1980). The perivitelline space and egg envelopes of bony fishes: a review. Copeia. 2, 210-26.

Linhart, O. \& Kudo, S. (1997). Surface ultrastructure of paddlefish egg before and after fertilization. J. Fish Biol. 51, 573-82.

Lönning, S., Kjorsvik, E. \& Davenport, J. (1984). The hardening process of the chorion of the cod, Gadus morhua L., and lampsucker, Cycloperus lumpus L. J. Fish Biol. 24, 505-22.

Marques, C., Nakaghi, L.S.O., Faustino, F., Ganeco, L.N. \& Senhorini, J.A. (2008). Observations of the embryonic development in Pseudoplatystoma coruscans (Siluriformes: Pimelodidae) under light and scanning electron microscopy. Zygote (Cambridge) (in press).

Moore, K.L. (2001). Embriologia Clínica. Quarta edição. Rio de Janeiro: Guanabara Koogan S.A.

Nakaghi, L.S.O., Marques, C., Faustino, F., Ganeco, L.N. \& Senhorini, J.A. (2006). Desenvolvimento embrionário do dourado (Salminus brasiliensis) por meio de microscopia eletrônica de varredura. Bol. Tec. CEPTA, 19, 9-19.

Nakatani, K., Agostinho, A.A., Baumgartner, G., Bialetzki, A., Sanches, P.V. \& Cavicchioli, M. (1999). Ovos e larvas de peixes de água doce, desenvolvimento e manual de identificação. Maringá: UEM Nupélia. 359 pp.

Ohta, T. (1985). Electron microscopy observations on sperm entry and pronuclear formation in naked eggs of the rose bitterling in polyspermic fertilization. J. Exp. Zool. 234, 27381.

Ohta, T. (1991). Initial stages of sperm-egg fusion in the freshwater teleost, Rhodeus ocellatus ocellatus. Anat. Rec. 229, 195-202.

Ohta, T. \& Nashirozawa, C. (1996). Sperm penetration and transformation of sperm entry site in egg of the freshwater 
teleost Rhodeus ocellatus ocellatus. J. Morph. 229, 191200.

Ohta, T., Iwamatsu, T., Tanaka, M. \& Yashimoto, Y. (1990). Cortical alveolus breakdown in the eggs of the freshwater teleost Rhodeus ocellatus ocellatus. Anat. Rec. 227, 486-96.

Paiva, M.P. (1982). Grandes Represas do Brasil. 292 pp. Brasília: Editerra.

Reynalte-Tataje, D., Zaniboni-Filho, E. \& Esquivel, J.R. (2004). Embryonic and larvae development of piracanjuba, Brycon orbignyanus Valenciennes, 1849 (Pisces, Characidae). Acta Sci. 26(1), 67-71.
Romagosa, E., Narahara, M.Y. \& Fenerich-Verani, N. (2001). Stages of embryonic development of the "matrinxã," Brycon cephalus (Pisces, Characidae). Bol. Inst. Pesca. 27(1), 27-32.

Schatten, G. (1999). Fertilization. In: Encyclopedia of Reproduction vol. 2. London: Academic Press.

Vaz, M.M., Torquato, V.C. \& Barbosa, N.D.C. (Org.) (2000). Guia Ilustrado de peixes da bacia do Rio Grande. Belo Horizonte: CEMIG/CETEC.

Vazzoler, A.E.A.M. (1996). Biologia da reprodução de peixes teleósteos: teoria e prática. Maringá: EDUEM. 169 pp. 